\title{
Therapeutics of Stem Cell Treatment in Anti-Aging and Rejuvenation
}

\author{
Da-Chuan Yeh1, Tzu-Min Chan ${ }^{2 *}$ \\ ${ }^{1}$ Division of General Internal Medicine and Cosmetic Clinic, Buddhist Tzu Chi General Hospital, Taiwan \\ ${ }^{2}$ General Education Center, Taiwan Shoufu University, Taiwan \\ Email: *ziv.j@yahoo.co.tw
}

How to cite this paper: Yeh, D.-C. and Chan, T.-M. (2018) Therapeutics of Stem Cell Treatment in Anti-Aging and Rejuvenation. Stem Cell Discovery, 8, 13-31. https://doi.org/10.4236/scd.2018.82002

Received: April 10, 2018

Accepted: April 27, 2018

Published: April 30, 2018

Copyright (c) 2018 by authors and Scientific Research Publishing Inc. This work is licensed under the Creative Commons Attribution International License (CC BY 4.0).

http://creativecommons.org/licenses/by/4.0/

\begin{abstract}
Aging populations are increasing the incidence of age-related diseases, resulting in problems at the individual and socioeconomic level. The need for effective strategies in regenerative medicine for the elderly is more important than ever. Previous studies have shown that the number and function of stem cells decline with age, thereby undermining endogenous repair processes. It has also been suggested that the aging-induced deterioration of stem cell function may play a key role in the pathophysiology of various aging-related diseases. Recent advances in our understanding of tissue regeneration and the development of methods aimed at inducing and differentiating pluripotent stem cells for cell replacement therapy which provides exciting opportunities for the treatment of degenerative diseases, such as those related to senility. In this review article, we examine several mechanisms that are believed to contribute to the aging-related dysfunction of stem cells associated with diseases of the immune system, cardiac tissue, neuronal system, articular cartilage, and skeletal muscle. We also discuss factors that affect the therapeutic potential of adult stem/progenitor cells as well as current trends in the treatment of these conditions using regenerative medicine.
\end{abstract}

\section{Keywords}

Stem Cell, Anti-Aging, Rejuvenation, Immune System, Cardiac Tissue, Central Nerve System, Articular Cartilage and Skeletal Muscle

\section{Introduction}

Aging-related tissue changes and stem cell depletion in mammals lead to imbalances in tissue homeostasis and decreased organ regenerative capacity [1] [2]. The mediation of aging by complex cellular and physiological processes is driven 
by various acquired and genetic factors [3]. The physiological processes of aging often lead to destructive diseases, such as dementia, autoimmunity, arthritis, cardiovascular disease, cancer, tissue degeneration, neuropathy, stroke, obesity, and depression [4] [5] [6] [7]. The effects of aging are particularly noticeable in retarded eyesight, hearing, muscle strength, and bone strength [8]. Regenerative medicine can reverse or inhibit many of these health problems through the use of endogenous stem cells or exogenous replacement cells derived from stem or progenitor cells to restore or rejuvenate tissue and maintain homeostasis [9] [10] [11]. This approach is a promising strategy for rehabilitation and reducing age-related diseases [12]. In this review, we discuss several mechanisms believed to contribute to aging-related stem cell dysfunction. We also briefly discuss the neutralizing ability of stem cells and other life extension factors used to treat conditions of the immune system [13], cardiac tissue [14], central nerve system [15], articular cartilage [16], and skeletal muscle [17]. Researchers have shown that stem cell interventions could one day be used to delay senescence and prolong lifespan.

\section{Impact of Stem Cell Senescence in Aging and Diseases}

Tissue-specific stem cells are capable of self-renewal and differentiation to produce mature effector cells, which play a crucial role in prolonging tissue function [3] [18]. Adult stem cells, also known as somatic stem cells, serve as self-renewing cell pools to supplement senescent cells and regenerate damaged tissues throughout the body. Mesenchymal stem cells [19], cartilage progenitor [20], satellite cells [21], and adipose derived stem cells [22] are pluripotent stem cells capable of differentiating into mesenchymal tissue cells. There is ample evidence that a decline in the number of stem cells is an important factor in the initiation of several diseases associated with the aging process [23]. It has been hypothesized that the loss of stem cell populations and/or activity over time contributes to this decline. Previous research has explored key molecular pathways that are often disrupted when tissue and stem cell senescence and degradation, and experimental evidence supports these pathways themselves can reverse the aging phenotype. However, the mechanisms related to the rejuvenation of tissues have yet to be fully elucidated [24].

Epigenetic regulation is essential for establishing and maintaining stem cell function, and evidence suggests that epigenetic dysregulation leads to potential changes in stem cells during aging [18] [25] [26] [27]. The term epigenetics refers to changes in gene expression that do not involve changes in the underlying DNA sequence [28] [29]. Hereditary changes in epigenetic landscapes produced in stem cells can be passed on to offspring with functional consequences exhibited in downstream lineages. Changes in dynamic chromatin structure, including DNA methylation and histone modifications, are keys to stem cell function. Protein coding information is encoded in the genome by the nucleotide sequence, whereas epigenetic information can be encoded by chemically modify- 
ing the cytosine base [30] [31] [32]. Methylated cytosine is found throughout the genome, mainly in the promoter region of housekeeping and developmental regulatory genes. The methylated cytosine is predominantly found within $\mathrm{CpG}$ dinucleotides [33]. Another epigenetic regulation that does not directly alter the nucleotide chemistry of DNA involves histone modification. Unlike genomic lesions that occur during aging, age-related epigenetic changes are not permanent. Appropriate epigenetic regulation of stem cells is critical to the maintenance of tissue, which is particularly important given that stem cells can genetically transmit epigenetic markers to their offspring.

Autophagy is one of the hallmarks of aging [34]. It is a constitutive pathway associated with damage to organelles and protein aggregates through a decline in the number and function of stem cells [3] [35]. Recent studies have shown that stem cells require autophagy to eliminate cellular waste generated during quiescence. Autophagy promotes cell survival by helping to maintain cell homeostasis and proper metabolic functions under conditions of stress and by maintaining bioenergetic levels and amino acid pools [36] [37]. Several studies have described the decline in autophagy activity and the expression of autophagic genes, such as ATG1, ATG5, ATG6, ATG7, ATG8, and ATG12 [38] [39] [40] [41]. Recent studies on muscle stem cells (MSCs) and hematopoietic stem cells (HSCs) have revealed impaired autophagy associated with a decline in stem cell activity [41] [42]. These findings indicate that at in advanced age, MSCs and HSCs lose their ability to regenerate and that defects in autophagy are present in aging stem cells. The effects of autophagy on maintaining cellular homeostasis open the door to novel therapies to deal with aging and age-related diseases.

It has been assumed that reactive oxygen species (ROS) may lead to a loss of differentiation [43] [44] [45]. Excessive production of ROS by environmental stresses triggers cellular senescence and the amorphous differentiation of MSCs. One member of the mitogen-activated protein kinase (MAPK) family, p38 MAPK, is an important mediator responsive to extracellular stressors [46] [47] [48]. The fact that p38 MAPK is involved in the molecular interaction during aging indicates that p53 is a major mediator of ROS-related signal transduction. The cyclin-dependent kinase inhibitor gene p16INK4a is believed to be a key factor in regulating oxidative stress-induced cell division and arresting the senescence of MSCs and tissue progenitor cells [49] [50]. It is generally believed that high levels of ROS promote senescence by inducing oxidative stress. This would mean that MSCs may contribute to organism aging by undermining tissue homeostasis.

Many types of monocytes are present in skeletal muscle, which are essential to the maintenance of stem cells, fibroblasts, and immune cells [23] [51] [52]. Age-related changes in the extracellular matrix (ECM), which can lead to pathogenicity, are associated with induced stiffness in skeletal muscle [53] [54]. These age-related changes affect stem cell behavior, and stromal cell proteins secreted by aged ECM and aged fibroblasts drive differentiation into fibroblasts 
[55]. Thus, senescence is associated with intensive ECM deposition and loss of stem cell function, leading to reductions in regenerative capacity and strength. Age-related changes in the density and biophysical properties (i.e., hardness) may have negative effects on the function of satellite cells. Directly or indirectly modifying ECM may provide a basis for age-related growth and insufficient strength [56] [57]. The regeneration of skeletal muscle depends on the dynamic interaction between muscle stem cells and the microenvironment or niche.

\section{Stem Cells for Anti-Aging and Rejuvenation}

Stem cells are characterized by their multiple-efficacy and self-renewal capabilities, resulting in progenitor or mature cells that can repair tissue and retain the characteristics of stem cells to ensure long-term maintenance of the stem cell pool [58] [59]. As stem cells age, their renewal ability deteriorates, and their ability to differentiate into various cell types is depleted. Based on current understanding of stem cells, it is feasible to design and test interventions to slow aging and improve health and longevity [8]. It is believed that stem cell failure contributes to a decline in health during aging; therefore, the development of effective methods to induce and differentiate pluripotent stem cells via cell replacement therapy provides an exciting avenue for the treatment of degenerative age-related diseases [12] [60] [61] [62]. It is believed that the regenerative potential of these cells is due to their high proliferation and differentiation capabilities, paracrine activity, and immune privilege [63]. Somatic stem cell populations differ according to the regenerative needs of the host tissue. In high turnover tissue, such as the gut or hematopoietic system, most stem cell or progenitor cell populations are active throughout life [64]. In organs lacking stem cells, inducing pluripotent stem cell (iPSC) to replace cells is a promising therapeutic approach for functional recovery [65] [66]. iPSCs restore the same developmental potential of embryonic stem cells, which means that they can then differentiate into any type of tissue. Stem cells play a key role in organogenesis and maintaining homeostasis throughout life, possess the ability to migrate long distances and target pathological conditions, express therapeutic genes, and respond to cues that redirect their differentiation into defective lineages [67]. This means that stem cells can be used for cell replacement as a therapeutic intervention aimed at mitigating the effects of aging.

\section{Immune System Rejuvenation}

In most species, including humans, the later stages of life see a decline in the overall maintenance of an organism and subsequent decline in health [68]. This also applies to hematopoietic systems, in which senescence is associated with increased susceptibility to hematological malignancies and other diseases. Hematopoietic stem cells are a continuous source of various lymphocytes and myeloid cells from early development through to old age [69] [70] [71]. Blood cells are responsible for the ongoing maintenance and immune protection of every cell 
type. This leads to the production of billions of new blood cells by hematopoietic stem cells every hour [3] [12]. At the population level, the adaptive immune responses of elderly individuals are retarded. Studies on the process of blood cell formation have revealed that aging reduces adaptive immune responses and hemocyte components, leading to an increase in the incidence of myeloid diseases, including cancer [4] [72].

Rejuvenation is meant to reverse aging rather than simply delay it. Rejuvenation can be achieved through the reconstitution of endogenous hematopoietic stem cells or the transplantation of pluripotent hematopoietic stem cells, usually derived from bone marrow, peripheral blood, or umbilical cord blood [4] [73] [74]. The pharmacological modulation of deregulated factors is one strategy aimed at the reconstitution of endogenous HSCs. Currently, this type of intervention has achieved only partial rejuvenation. Previous proof-of-concept studies have shown that modulation of the HSC aging state can be achieved by targeting mTOR and cdc42 using exogenous agents [75] [76]. The recent use of novel compounds for the ablation of senescent cells has led to the renewal of hematopoietic stem cells and muscle stem cells in wild type aged mice, further demonstrating the efficacy of adult stem cells in overcoming the effects of aging [77]. Most research on the use of allogeneic hematopoietic stem cells for the treatment of hematological malignancies in the 1980s and early 1990s was restricted to young patients [78]. Hematopoietic stem cell transplantation is now considered a mature technology and remains an effective method for the treatment of patients presenting hematological symptoms.

\section{Cardiac Rejuvenation}

We are still far from a definite quantitative measure of cardiac turnover; however, it has finally been accepted that heart muscle cells can be regenerated after birth [24] [79] [80]. Nonetheless, mature cardiomyocytes are withdrawn from the cell cycle soon after birth [81] [82] [83]. The metabolism of cardiomyocytes requires the contribution of immature cells to myocyte, which are differentiation from cardiac stem cells, replacement repeatedly. However, senescent blasts and cardiomyocytes accumulate in the myocardium of elderly patients with severe systolic dysfunction. Patients with severe obstructive cardiac disease caused by the narrowing of atherosclerotic plaques present tissue retention and a reduction in the functionality of circulating vascular stem/progenitor cells to repair tissue damage [84]. This has led a number of researchers to use stem cell transplantation as a means to regenerate tissue heart in a process referred to as heart rejuvenation [24].

Researchers have recently succeeded in treating cardiovascular diseases using alternative approaches to regenerative medicine [84]. Systemic interventions involving the pharmacological removal of senescent cells inhibit pro-survival and anti-apoptotic pathways in senescent cells [85] [86]. The restoration of a juvenile microenvironment through the administration of systemic factors or the inhibi- 
tion of pathways alters with age [24] [87] [88] [89]. Researchers have also investigated cell therapies involving the administration of young, healthy stem cells to a diseased heart to provide protection from cardiomyocyte senescence and promote cardiac repair [24] [90] [91]. They also investigated the ex vivo rejuvenation of reparative cells through the in vitro pharmacological pretreatment of stem cells isolated from old diseased animals followed by in vivo delivery. This approach was aimed at suppressing or activating modifications induced by the aging process, and epigenetic drugs were shown to at least partially restore changes associated with systemic disease [90] [92] [93]. Another approach was the genetic modification of stem cells to enhance functionality, such as the overexpression of the pro-survival kinase Pim-1 or nucelostemin to reverse cellular senescence [94] [95] [96]. Further studies have demonstrated the potential of these alternative therapeutic interventions.

\section{Nerve System Rejuvenation}

For decades, research proceeded on the assumption that the nervous system of adult mammals is unable to produce new neurons. However, the identification of neurogenic regions in the adult brain has prompted intense activity in the field of adult neurogenesis [97]. Most neurons are mitotic, and slow-cycle neural stem cells (NSC) maintain neural regeneration in specific areas of the mammalian brain during adulthood [98] [99]. Age-induced reduction in the number of satellite cells and neural stem cells undermines nerve regeneration [100]. Aging of the central nervous system is associated with the progressive loss of function, which can be exacerbated by neurodegenerative diseases, such as Alzheimer's disease, dementia, stroke, and Parkinson's disease [97] [101] [102] [103]. At the cellular level, senescence of the central nervous system is accompanied by a number of changes that impair cell function, including elevated levels of oxidative stress and oxidative damage associated with proteins and DNA [104]. It has also been linked to impaired cellular metabolism, lipid and protein by-products, and the accumulation of advanced glycation end products [97] [105]. The most notable age-related changes in the brain are associated with cognition and plasticity. Even in the absence of disease, aging can negatively affect nerve function. Recent data suggest that age-related defects in neural stem cells can be reversed through the reactivation of telomerase, suggesting that aged oligodendrocyte precursor cells can theoretically be used to preserve the regeneration of myelin sheaths [106]. In the adult central nervous system, remyelination is a spontaneous regenerative process that restores skip conduction, prevents axonal degeneration, and promotes functional recovery [107].

Most previous studies reported that cell therapy may be able to replenish lost cells and promote neuronal regeneration, protect neuron survival as well as play a role in overcoming permanent paralysis and sensory loss and restoring neurological function [108] [109]. Unfortunately, mechanisms for determining treatment capacity have yet to be identified [101] [110]. Previously researches im- 
plied that possible mechanisms may include the following: 1) the promotion of angiogenesis, 2) induced neuronal differentiation and neurogenesis, 3) reduced reactive gliosis, 4) the inhibition of apoptosis, 5) the expression of neurotrophic factors, 6) immunomodulatory functions, and 7) the promotion of neuronal integration [101]. The two primary cell replacement strategies involve 1) the transplantation of exogenous tissue and 2) the endogenous activation of cell proliferation. Tissue can be transplanted directly in order to replace lost tissue. Genetically engineered cells can also be implanted for the secretion of factors that promote survival and/or proliferation [97] [111] [112]. The specialized microenvironment of the neural niche ensures that neural stem cells (NSCs) self-renew and differentiate but mainly enter the neurons [108] [113]. Thus, understanding the physiological characteristics of NSCs and how they are affected by changes in pathological conditions could open the door to exploiting the plasticity of NSCs for the prevention and/or treatment of degenerative diseases.

\section{Articular Cartilage Rejuvenation}

Articular cartilage injury is a debilitating disease that can result in fibrillation and the subsequent deterioration of the peripheral articular surface and may also involve the subchondral bone, thereby facilitating the development of osteoarthritis [114]. The special composition of the ECM gives it viscoelastic properties, which facilitate the normal function of the ECM. Collagen is hyaline cartilage composed of $60 \%$ (by dry weight) chondrocytes. Fibrocartilage and elastic cartilage are two other types of cartilage differing in ECM and cell components [115]. Age-induced changes in articular cartilage include chondrocytes acquiring a secretory phenotype, chondrocyte sensitivity to growth factors, the destructive effects of chronic ROS, and glycosylation of end products [116]. This disturbs the balance between anabolic activity and the destructive processes of chondrocytes. As the matrix decreases, articular cartilage becomes increasingly thin, the hydration of cartilage decreases, and the number of cartilage cells also decreases [115]. It appears that the bioactive paracrine factors secreted by mesenchymal stem cells (MSC) can have beneficial effects in regulating the microenvironment of damaged tissue, leading to more favorable conditions for tissue regeneration [117]. MSCs secrete a range of paracrine factors, collectively referred to as secreted proteomes, which perform a variety of biological functions, including immune regulation, angiogenesis, anti-apoptosis, anti-oxidation, cell homing, and the promotion of cell differentiation. Most previous studies have focused on the clinical benefits of MSC treatment, regardless of the source of the cells, the indications, or the mode of administration [114]. MSCs have been used in cell therapy to promote the repair of cartilage, muscle, or bone [115]. These cells are typically harvested from bone marrow and are characterized according to the stimulatory factors they provide [118]. Elucidating the mechanism that promotes the aging of articular cartilage could lead to treatments aimed at slowing aging-related changes or promoting the regeneration of articular cartilage. 


\section{Skeletal Muscle Rejuvenation}

The extraordinary regenerative capacity of skeletal muscle can be attributed to a reserve pool of muscle-resident satellite cells located in the niche between muscles. These cells are essential to the repair and regeneration of muscle throughout life [62]. Recent studies have shown that cellular and extracellular factors are dysregulated during aging [55] [119] [120]. Aging is associated with a progressive loss of tissue function associated with a decrease in the functionality of muscle satellite cells and the total size of the muscle stem cell pool [121]. The aging of muscle is characterized by a decrease in repair capacity. Aging satellite cells show evidence of several intrinsic cellular changes associated with genomic instability, DNA damage, oxidative damage, and the deterioration of mitochondrial function [122]. Changes in homeostasis may explain the reduction in antioxidant activity, changes in protein folding, decreased myogenic differentiation, and tendency of these cells to adopt fibroblastic and adipogenic fates [123]. Another intrinsic change observed in the satellite cells of the elderly is an imbalance in protein homeostasis [35]. Satellite cells are also affected by the local microenvironment and systemic circulation, both of which are affected by aging. This means that changes in intrinsic cellular function and regenerative environmental cues tend to impair stem cell activity and reduce the regenerative capacity of aging muscle.

Interventions aimed at reversing age-related changes in satellite cells or their niche have been shown to partially restore the ability of aging muscle stem cells to regenerate. Current attempts to recover aged satellite cells include the genetic and pharmacological inhibition of p16INK4a [62] [124], STAT3 and p38 MAPK [125] [126] [127], autophagic flux [35], and $\mathrm{NAD}^{+}$recruitment [128] as well as the administration of hormones to revitalize oxytocin [129]. Satellite cells are essential to the maintenance and repair of many types of adult tissue during normal physiological processes as well as to the response to injury or aging [130]. Recent advances in the isolation of muscle satellite cells and the elucidation of the cellular and molecular media that control their activity have indicated that these cells are a promising therapeutic target [131]. Satellite cell-based therapy could involve the direct replacement of cells or the development of drugs that enhance endogenous muscle repair mechanisms. Satellite cells are a population of major regenerative cell in adult skeletal muscle that is capable of supporting multiple rounds of mature myofiber regeneration. These cells are attractive candidates for Duchenne muscular dystrophy, is a severe type of muscular dystrophy, and related disorders [132] [133] [134]. Previous studies have shown that at least some of the muscle satellite cells exhibit the characteristics of stem cells, such as self-renewal and differentiation. Transplanting these cells into damaged or malnourished muscle could produce permanent disease-resistant wild-type copies of genes that can incorporate into existing muscle fibers [132].

\section{Conclusion}

Over the past decade, researchers have made tremendous progress in under- 
standing stem cell aging and the molecular mechanisms underlying this process [34]. Previous studies have also confirmed the extrinsic ingredients, and transplantation trials have identified the intrinsic components that cause an age-dependent decline in the number and function of stem cells [130]. This impairment can be attributed to changes in the intrinsic pathway of cells and the surrounding environment. Regenerative therapies focus on stem cells and other life-prolonging factors in an attempt to reverse aging. Clinical trials must also be conducted to determine whether genetically reprogramming stem cells delay senescence and enhance regeneration and whether the application of stem cells in aging individuals is ultimately approved. The ex vivo genetic modification of stem cells may also provide an effective strategy for rejuvenating older stem cells and diseased organs. Improved protocols for the rejuvenation of aging stem cells could help to improve the preparation and clinical application of stem cells harvested from aging tissues as well as their products.

\section{Conflicts of Interest}

The authors declare no conflicts of interest regarding the publication of this paper.

\section{References}

[1] Povsic, T.J., Sloane, R., Green, J.B., Zhou, J., Pieper, C.F., Pearson, M.P., Peterson, E.D., Cohen, H.J. and Morey, M.C. (2013) Depletion of Circulating Progenitor Cells Precedes overt Diabetes: A Substudy from the VA Enhanced Fitness Trial. Journal of Diabetes and Its Complications, 27, 633-636. https://doi.org/10.1016/j.jdiacomp.2013.08.004

[2] Harfouche, G. and Martin, M.T. (2010) Response of Normal Stem Cells to Ionizing Radiation: A Balance between Homeostasis and Genomic Stability. Mutation Research/Reviews in Mutation Research, 704, 167-174.

https://doi.org/10.1016/j.mrrev.2010.01.007

[3] Ahmed, A.S., Sheng, M.H., Wasnik, S., Baylink, D.J. and Lau. K.W. (2017) Effect of Aging on Stem Cells. World Journal of Experimental Medicine, 7, 1-10. https://doi.org/10.5493/wjem.v7.i1.1

[4] Wahlestedt, M., Pronk, C.J. and Bryder, D. (2015) Concise Review: Hematopoietic Stem Cell Aging and the Prospects for Rejuvenation. STEM CELLS Translational Medicine, 4, 186-194. https://doi.org/10.5966/sctm.2014-0132

[5] Lo, R.Y. (2017) The Borderland between Normal Aging and Dementia. Tzu-Chi Medical Journal, 29, 65-71.

[6] Cheng, Y., Schwartz, J., Sparrow, D., Aro, A., Weiss, S.T. and Hu, H. (2001) Bone Lead and Blood Lead Levels in Relation to Baseline Blood Pressure and the Prospective Development of Hypertension: The Normative Aging Study. American Journal of Epidemiology, 153, 164-171. https://doi.org/10.1093/aje/153.2.164

[7] Kumar, A. and Foster, T.C. (2007) Neurophysiology of Old Neurons and Synapses, In: Riddle, D.R., Ed., Brain Aging: Models, Methods, and Mechanisms, CRC Press, Boca Raton. https://doi.org/10.1201/9781420005523.ch10

[8] Ullah, M. and Sun, Z. (2018) Stem Cells and Anti-Aging Genes: Double-Edged Sword-Do the Same Job of Life Extension. Stem Cell Research \& Therapy, 9, 3. 
https://doi.org/10.1186/s13287-017-0746-4

[9] Grade, S. and Gotz, M. (2017) Neuronal Replacement Therapy: Previous Achievements and Challenges Ahead. NPJ Regenerative Medicine, 2, Article No. 29. https://doi.org/10.1038/s41536-017-0033-0

[10] Okere, B., Lucaccioni, L., Dominici, M. and Iughetti, L. (2016) Cell Therapies for Pancreatic Beta-Cell Replenishment. Italian Journal of Pediatrics, 42, 62. https://doi.org/10.1186/s13052-016-0273-4

[11] Petersen, G.F. and Strappe, P.M. (2016) Generation of Diverse Neural Cell Types through Direct Conversion. World Journal of Stem Cells, 8, 32-46. https://doi.org/10.4252/wjsc.v8.i2.32

[12] Neves, J., Sousa-Victor, P. and Jasper, H. (2017) Rejuvenating Strategies for Stem Cell-Based Therapies in Aging. Cell Stem Cell, 20, 161-175. https://doi.org/10.1016/j.stem.2017.01.008

[13] Anastassova-Kristeva, M. (2003) The Origin and Development of the Immune System with a View to Stem Cell Therapy. Journal of Hematotherapy \& Stem Cell Research, 12, 137-154. https://doi.org/10.1089/152581603321628287

[14] Ummarino, D. (2017) Cell Therapy: Autologous Cardiac Stem Cells for Congenital HF. Nature Reviews Cardiology, 14, 128. https://doi.org/10.1038/nrcardio.2017.5

[15] Xiao, L., Saiki, C. and Ide, R. (2014) Stem Cell Therapy for Central Nerve System Injuries: Glial Cells Hold the Key. Neural Regeneration Research, 9, 1253-1260. https://doi.org/10.4103/1673-5374.137570

[16] Park, Y.B., Ha, C.W., Rhim, J.H. and Lee, H.J. (2017) Stem Cell Therapy for Articular Cartilage Repair: Review of the Entity of Cell Populations Used and the Result of the Clinical Application of Each Entity. The American Journal of Sports Medicine, 46, 2540-2552.

[17] Bhagavati, S. (2008) Stem Cell Based Therapy for Skeletal Muscle Diseases. Current Stem Cell Research \& Therapy, 3, 219-228. https://doi.org/10.2174/157488808785740343

[18] Beerman, I. and Rossi, D.J. (2015) Epigenetic Control of Stem Cell Potential during Homeostasis, Aging, and Disease. Cell Stem Cell, 16, 613-625. https://doi.org/10.1016/j.stem.2015.05.009

[19] Giri, T.K., Alexander, A., Agrawal, M., Saraf, S., Saraf, S. and Ajazuddin (2018) Current Status of Stem Cell Therapies in Tissue Repair and Regeneration. Current Stem Cell Research \& Therapy. https://doi.org/10.2174/1574888X13666180502103831

[20] Kristjansson, B. and Honsawek, S. (2017) Mesenchymal Stem Cells for Cartilage Regeneration in Osteoarthritis. World Journal of Orthopedics, 8, 674-680. https://doi.org/10.5312/wjo.v8.i9.674

[21] Fishman, J.M., Tyraskis, A., Maghsoudlou, P., Urbani, L., Totonelli, G., Birchall, M.A. and De Coppi, P. (2013) Skeletal Muscle Tissue Engineering: Which Cell to Use? Tissue Engineering Part B: Reviews, 19, 503-515. https://doi.org/10.1089/ten.teb.2013.0120

[22] Chan, T.M., Harn, H.J., Lin, H.P., Chiu, S.C., Lin, P.C., Wang, H.I., Ho, L.I., Chuu, C.P., Chiou, T.W., Hsieh, A.C., Chen, Y.W., Ho, W.Y. and Lin, S.Z. (2014) The Use of ADSCs as a Treatment for Chronic Stroke. Cell Transplant, 23, 541-547. https://doi.org/10.3727/096368914X678409

[23] Garg, K. and Boppart, M.D. (1985) Influence of Exercise and Aging on Extracellular Matrix Composition in the Skeletal Muscle Stem Cell Niche. Journal of Applied 
Physiology, 121, 1053-1058.

[24] Cesselli, D., Aleksova, A., Mazzega, E., Caragnano, A. and Beltrami, A.P. (2018) Cardiac Stem Cell Aging and Heart Failure. Pharmacological Research, 127, 26-32. https://doi.org/10.1016/j.phrs.2017.01.013

[25] Cheng, D., Wang, S., Jia, W., Zhao, Y., Zhang, F., Kang, J. and Zhu, J. (2017) Regulation of Human and Mouse Telomerase Genes by Genomic Contexts and Transcription Factors during Embryonic Stem Cell Differentiation. Scientific Reports, 7, Article No. 16444. https://doi.org/10.1038/s41598-017-16764-w

[26] Mattiucci, D., Maurizi, G., Leoni, P. and Poloni, A. (2018) Aging- and Senescence-Associated Changes of Mesenchymal Stromal Cells in Myelodysplastic Syndromes. Cell Transplant, 27, 754-764. https://doi.org/10.1177/0963689717745890

[27] Parsons, X.H. (2013) Human Stem Cell Derivatives Retain More Open Epigenomic Landscape When Derived from Pluripotent Cells than from Tissues. Journal of Regenerative Medicine, 1, pii: 1000103.

[28] Kramer, A. and Challen, G.A. (2017) The Epigenetic Basis of Hematopoietic Stem Cell Aging. Seminars in Hematology, 54, 19-24. https://doi.org/10.1053/j.seminhematol.2016.10.006

[29] Noguchi, H., Miyagi-Shiohira, C. and Nakashima, Y. (2018) Induced Tissue-Specific Stem Cells and Epigenetic Memory in Induced Pluripotent Stem Cells. International Journal of Molecular Sciences, 19, pii: E930.

[30] Mortada, I. and Mortada, R. (2018) Epigenetic Changes in Mesenchymal Stem Cells Differentiation. European Journal of Medical Genetics, 61, 114-118. https://doi.org/10.1016/j.ejmg.2017.10.015

[31] Sharma, S. and Gurudutta, G. (2016) Epigenetic Regulation of Hematopoietic Stem Cells. International Journal of Stem Cells, 9, 36-43. https://doi.org/10.15283/ijsc.2016.9.1.36

[32] Han, J.W. and Yoon, Y.S. (2012) Epigenetic Landscape of Pluripotent Stem Cells. Antioxidants \& Redox Signaling, 17, 205-223. https://doi.org/10.1089/ars.2011.4375

[33] Horii, T. and Hatada, I. (2016) Regulation of CpG Methylation by Dnmt and Tet in Pluripotent Stem Cells. Journal of Reproduction and Development, 62, 331-335. https://doi.org/10.1262/jrd.2016-046

[34] Revuelta, M. and Matheu, A. (2017) Autophagy in Stem Cell Aging. Aging Cell, 16, 912-915. https://doi.org/10.1111/acel.12655

[35] Garcia-Prat, L., Martinez-Vicente, M., Perdiguero, E., Ortet, L., Rodriguez-Ubreva, J., Rebollo, E., Ruiz-Bonilla, V., Gutarra, S., Ballestar, E., Serrano, A.L., Sandri, M. and Munoz-Canoves, P. (2016) Autophagy Maintains Stemness by Preventing Senescence. Nature, 529, 37-42. https://doi.org/10.1038/nature16187

[36] Ma, Y., Qi, M., An, Y., Zhang, L., Yang, R., Doro, D.H., Liu, W. and Jin, Y. (2018) Autophagy Controls Mesenchymal Stem Cell Properties and Senescence during Bone Aging. Aging Cell, 17.

[37] Garcia-Prat, L., Munoz-Canoves, P. and Martinez-Vicente, M. (2016) Dysfunctional Autophagy Is a Driver of Muscle Stem Cell Functional Decline with Aging. Autophagy, 12, 612-613. https://doi.org/10.1080/15548627.2016.1143211

[38] Gomez-Puerto, M.C., Folkerts, H., Wierenga, A.T., Schepers, K., Schuringa, J.J., Coffer, P.J. and Vellenga, E. (2016) Autophagy Proteins ATG5 and ATG7 Are Essential for the Maintenance of Human CD34(+) Hematopoietic Stem-Progenitor Cells. Stem Cells, 34, 1651-1663. https://doi.org/10.1002/stem.2347

[39] Rothe, K., Lin, H., Lin, K.B., Leung, A., Wang, H.M., Malekesmaeili, M., Brinkman, 
R.R., Forrest, D.L., Gorski, S.M. and Jiang, X. (2014) The Core Autophagy Protein ATG4B Is a Potential Biomarker and Therapeutic Target in CML Stem/Progenitor Cells. Blood, 123, 3622-3634. https://doi.org/10.1182/blood-2013-07-516807

[40] Yang, M., Pi, H., Li, M., Xu, S., Zhang, L., Xie, J., Tian, L., Tu, M., He, M., Lu, Y., $\mathrm{Yu}, \mathrm{Z}$. and Zhou, Z. (2016) From the Cover: Autophagy Induction Contributes to Cadmium Toxicity in Mesenchymal Stem Cells via AMPK/FOXO3a/BECN1 Signaling. Toxicological Sciences, 154, 101-114. https://doi.org/10.1093/toxsci/kfw144

[41] Garcia-Prat, L., Munoz-Canoves, P. and Martinez-Vicente, M. (2017) Monitoring Autophagy in Muscle Stem Cells. Methods in Molecular Biology, 1556, 255-280. https://doi.org/10.1007/978-1-4939-6771-1_14

[42] Cao, Y., Zhang, S., Yuan, N., Wang, J., Li, X., Xu, F., Lin, W., Song, L., Fang, Y., Wang, Z., Wang, Z., Zhang, H., Zhang, Y., Zhao, W., Hu, S., Zhang, X. and Wang, J. (2015) Hierarchal Autophagic Divergence of Hematopoietic System. The Journal of Biological Chemistry, 290, 23050-23063. https://doi.org/10.1074/jbc.M115.650028

[43] Yang, S.R., Park, J.R. and Kang, K.S. (2015) Reactive Oxygen Species in Mesenchymal Stem Cell Aging: Implication to Lung Diseases. Oxidative Medicine and Cellular Longevity, 2015, Article ID: 486263. https://doi.org/10.1155/2015/486263

[44] Lleonart, M.E., Abad, E., Graifer, D. and Lyakhovich, A. (2017) Reactive Oxygen Species-Mediated Autophagy Defines the Fate of Cancer Stem Cells. Antioxidants \& Redox Signaling.

[45] Song, S.H., Kim, K., Park, J.J., Min, K.H. and Suh, W. (2014) Reactive Oxygen Species Regulate the Quiescence of CD34-Positive Cells Derived from Human Embryonic Stem Cells. Cardiovascular Research, 103, 147-155. https://doi.org/10.1093/cvr/cvu106

[46] Matsuda, S., Nakagawa, Y., Kitagishi, Y., Nakanishi, A. and Murai, T. (2018) Reactive Oxygen Species, Superoxide Dimutases, and PTEN-p53-AKT-MDM2 Signaling Loop Network in Mesenchymal Stem/Stromal Cells Regulation. Cells, 7, E36.

[47] Li, J., Zhao, Z., Liu, J., Huang, N., Long, D., Wang, J., Li, X. and Liu, Y. (2010) MEK/ERK and p38 MAPK Regulate Chondrogenesis of Rat Bone Marrow Mesenchymal Stem Cells through Delicate Interaction with TGF-Beta1/Smads Pathway. Cell Proliferation, 43, 333-343. https://doi.org/10.1111/j.1365-2184.2010.00682.x

[48] Niu, Z., Mu, H., Zhu, H., Wu, J. and Hua, J. (2017) p38 MAPK Pathway Is Essential for Self-Renewal of Mouse Male Germline Stem Cells (mGSCs). Cell Proliferation, 50. https://doi.org/10.1111/cpr.12314

[49] Mas-Bargues, C., Vina-Almunia, J., Ingles, M., Sanz-Ros, J., Gambini, J., Ibanez-Cabellos, J.S., Garcia-Gimenez, J.L., Vina, J. and Borras, C. (2017) Role of p16(INK4a) and BMI-1 in Oxidative Stress-Induced Premature Senescence in Human Dental Pulp Stem Cells. Redox Biology, 12, 690-698. https://doi.org/10.1016/j.redox.2017.04.002

[50] Stepanova, L. and Sorrentino, B.P. (2005) A Limited Role for p16Ink4a and p19Arf in the Loss of Hematopoietic Stem Cells during Proliferative Stress. Blood, 106, 827-832. https://doi.org/10.1182/blood-2004-06-2242

[51] Chan, T.M., Lin, H.P. and Lin, S.Z. (2014) In Situ Altering of the Extracellular Matrix to Direct the Programming of Endogenous Stem Cells. Stem Cells, 32, 1989-1990. https://doi.org/10.1002/stem.1693

[52] Syverud, B.C., Lee, J.D., VanDusen, K.W. and Larkin, L.M. (2014) Isolation and Purification of Satellite Cells for Skeletal Muscle Tissue Engineering. Journal of Regenerative Medicine, 3, pii: 117.

[53] Qiu, X., Liu, S., Zhang, H., Zhu, B., Su, Y., Zheng, C., Tian, R., Wang, M., Kuang, 
H., Zhao, X. and Jin, Y. (2018) Mesenchymal Stem Cells and Extracellular Matrix Scaffold Promote Muscle Regeneration by Synergistically Regulating Macrophage Polarization toward the M2 Phenotype. Stem Cell Research \& Therapy, 9, 88. https://doi.org/10.1186/s13287-018-0821-5

[54] Brzoska, E., Ciemerych, M.A., Przewozniak, M. and Zimowska, M. (2011) Regulation of Muscle Stem Cells Activation: The Role of Growth Factors and Extracellular Matrix. Vitamins and Hormones, 87, 239-276. https://doi.org/10.1016/B978-0-12-386015-6.00031-7

[55] Stearns-Reider, K.M., D’Amore, A., Beezhold, K., Rothrauff, B., Cavalli, L., Wagner, W.R., Vorp, D.A., Tsamis, A., Shinde, S., Zhang, C., Barchowsky, A., Rando, T.A., Tuan, R.S. and Ambrosio, F. (2017) Aging of the Skeletal Muscle Extracellular Matrix Drives a Stem Cell Fibrogenic Conversion. Aging Cell, 16, 518-528. https://doi.org/10.1111/acel.12578

[56] Suzuki, S., Narita, Y., Yamawaki, A., Murase, Y., Satake, M., Mutsuga, M., Okamoto, H., Kagami, H., Ueda, M. and Ueda, Y. (2010) Effects of Extracellular Matrix on Differentiation of Human Bone Marrow-Derived Mesenchymal Stem Cells into Smooth Muscle Cell Lineage: Utility for Cardiovascular Tissue Engineering. Cells Tissues Organs, 191, 269-280. https://doi.org/10.1159/000260061

[57] Merritt, E.K., Cannon, M.V., Hammers, D.W., Le, L.N., Gokhale, R., Sarathy, A., Song, T.J., Tierney, M.T., Suggs, L.J., Walters, T.J. and Farrar, R.P. (2010) Repair of Traumatic Skeletal Muscle Injury with Bone-Marrow-Derived Mesenchymal Stem Cells Seeded on Extracellular Matrix. Tissue Engineering Part A, 16, 2871-2881. https://doi.org/10.1089/ten.tea.2009.0826

[58] Mendelsohn, A.R. and Larrick, J.W. (2013) Rejuvenation of Aging Hearts. Rejuvenation Research, 16, 330-332. https://doi.org/10.1089/rej.2013.1462

[59] Ocampo, A., Reddy, P. and Belmonte, J.C.I. (2016) Anti-Aging Strategies Based on Cellular Reprogramming. Trends in Molecular Medicine, 22, 725-738. https://doi.org/10.1016/j.molmed.2016.06.005

[60] Wang, Y. and Xie, T. (2014) Extracellular, Stem Cells and Regenerative Ophthalmology. Journal of Glaucoma, 23, S30-S33. https://doi.org/10.1097/IJG.0000000000000112

[61] Bhattacharya, S., Gangaraju, R. and Chaum, E. (2017) Recent Advances in Retinal Stem Cell Therapy. Current Molecular Biology Reports, 3, 172-182.

[62] Bengal, E., Perdiguero, E., Serrano, A.L. and Munoz-Canoves, P. (2017) Rejuvenating Stem Cells to Restore Muscle Regeneration in Aging. F1000Research, 6, 76. https://doi.org/10.12688/f1000research.9846.1

[63] Efimenko, A.Y., Kochegura, T.N., Akopyan, Z.A. and Parfyonova, Y.V. (2015) Autologous Stem Cell Therapy: How Aging and Chronic Diseases Affect Stem and Progenitor Cells. BioResearch Open Access, 4, 26-38. https://doi.org/10.1089/biores.2014.0042

[64] Mimeault, M., Hauke, R. and Batra, S.K. (2007) Stem Cells: A Revolution in Therapeutics-Recent Advances in Stem Cell Biology and Their Therapeutic Applications in Regenerative Medicine and Cancer Therapies. Clinical Pharmacology \& Therapeutics, 82, 252-264. https://doi.org/10.1038/sj.clpt.6100301

[65] Bhere, D., Khajuria, R.K., Hendriks, W.T., Bandyopadhyay, A., Bagci-Onder, T. and Shah, K. (2018) Stem Cells Engineered During Different Stages of Reprogramming Reveal Varying Therapeutic Efficacies. Stem Cells, 36, 932-942. https://doi.org/10.1002/stem.2805

[66] Dai, X., Liu, P., Lau, A.W., Liu, Y. and Inuzuka, H. (2014) Acetylation-Dependent 
Regulation of Essential iPS-Inducing Factors: A Regulatory Crossroad for Pluripotency and Tumorigenesis. Cancer Medicine, 3, 1211-1224. https://doi.org/10.1002/cam4.298

[67] Snyder, E.Y. and Loring, J.F. (2005) A Role for Stem Cell Biology in the Physiological and Pathological Aspects of Aging. Journal of the American Geriatrics Society, 53, S287-S291. https://doi.org/10.1111/j.1532-5415.2005.53491.x

[68] Wahlestedt, M. and Bryder, D. (2017) The Slippery Slope of Hematopoietic Stem Cell Aging. Experimental Hematology, 56, 1-6. https://doi.org/10.1016/j.exphem.2017.09.008

[69] Guidi, N. and Geiger, H. (2017) Rejuvenation of Aged Hematopoietic Stem Cells. Seminars in Hematology, 54, 51-55. https://doi.org/10.1053/j.seminhematol.2016.10.005

[70] Laurenti, L., Sora, F., Piccirillo, N., Chiusolo, P., Cicconi, S., Rutella, S., Serafini, R., Garzia, M.G., Leone, G. and Sica, S. (2001) Immune Reconstitution after Autologous Selected Peripheral Blood Progenitor Cell Transplantation: Comparison of Two CD34+ Cell-Selection Systems. Transfusion, 41, 783-789. https://doi.org/10.1046/j.1537-2995.2001.41060783.x

[71] Wang, H., Pierce, L.J. and Spangrude, G.J. (2005) Lymphoid Potential of Primitive Bone Marrow Progenitors Evaluated in Vitro. Annals of the New York Academy of Sciences, 1044, 210-219. https://doi.org/10.1196/annals.1349.026

[72] Redecke, V., Wu, R., Zhou, J., Finkelstein, D., Chaturvedi, V., High, A.A. and Hacker, H. (2013) Hematopoietic Progenitor Cell Lines with Myeloid and Lymphoid Potential. Nature Methods, 10, 795-803. https://doi.org/10.1038/nmeth.2510

[73] Felfly, H. and Haddad, G.G. (2014) Hematopoietic Stem Cells: Potential New Applications for Translational Medicine. Journal of Stem Cells, 9, 163-197.

[74] Bhatwadekar, A.D., Duan, Y., Korah, M., Thinschmidt, J.S., Hu, P., Leley, S.P., Caballero, S., Shaw, L., Busik, J. and Grant, M.B. (2017) Hematopoietic Stem/Progenitor Involvement in Retinal Microvascular Repair during Diabetes: Implications for Bone Marrow Rejuvenation. Vision Research, 139, 211-220. https://doi.org/10.1016/j.visres.2017.06.016

[75] Chen, C., Liu, Y., Liu, Y. and Zheng, P. (2009) mTOR Regulation and Therapeutic Rejuvenation of Aging Hematopoietic Stem Cells. Science Signaling, 2, ra75. https://doi.org/10.1126/scisignal.2000559

[76] Florian, M.C., Dorr, K., Niebel, A., Daria, D., Schrezenmeier, H., Rojewski, M., Filippi, M.D., Hasenberg, A., Gunzer, M., Scharffetter-Kochanek, K., Zheng, Y. and Geiger, H. (2012) Cdc42 Activity Regulates Hematopoietic Stem Cell Aging and Rejuvenation. Cell Stem Cell, 10, 520-530. https://doi.org/10.1016/j.stem.2012.04.007

[77] Chang, J., Wang, Y., Shao, L., Laberge, R.M., Demaria, M., Campisi, J., Janakiraman, K., Sharpless, N.E., Ding, S., Feng, W., Luo, Y., Wang, X., Aykin-Burns, N., Krager, K., Ponnappan, U., Hauer-Jensen, M., Meng, A. and Zhou, D. (2016) Clearance of Senescent Cells by ABT263 Rejuvenates Aged Hematopoietic Stem Cells in Mice. Nature Medicine, 22, 78-83. https://doi.org/10.1038/nm.4010

[78] Metafuni, E., Chiusolo, P., Laurenti, L., Sora, F., Giammarco, S., Bacigalupo, A., Leone, G. and Sica, S. (2018) Allogeneic Hematopoietic Stem Cell Transplantation in Therapy-Related Myeloid Neoplasms (t-MN) of the Adult: Monocentric Observational Study and Review of the Literature. Mediterranean Journal of Hematology and Infectious Diseases, 10, e2018005. https://doi.org/10.4084/mjhid.2018.005

[79] Bergmann, O., Bhardwaj, R.D., Bernard, S., Zdunek, S., Barnabe-Heider, F., Walsh, 
S., Zupicich, J., Alkass, K., Buchholz, B.A., Druid, H., Jovinge, S. and Frisen, J. (2009) Evidence for Cardiomyocyte Renewal in Humans. Science, 324, 98-102. https://doi.org/10.1126/science.1164680

[80] Senyo, S.E., Steinhauser, M.L., Pizzimenti, C.L., Yang, V.K., Cai, L., Wang, M., Wu, T.D., Guerquin-Kern, J.L., Lechene, C.P. and Lee, R.T. (2013) Mammalian Heart Renewal by Pre-Existing Cardiomyocytes. Nature, 493, 433-436. https://doi.org/10.1038/nature11682

[81] Ahuja, P., Sdek, P. and MacLellan, W.R. (2007) Cardiac Myocyte Cell Cycle Control in Development, Disease, and Regeneration. Physiological Reviews, 87, 521-544. https://doi.org/10.1152/physrev.00032.2006

[82] Oyama, K., El-Nachef, D., Zhang, Y., Sdek, P. and MacLellan, W.R. (2014) Epigenetic Regulation of Cardiac Myocyte Differentiation. Frontiers in Genetics, 5, 375. https://doi.org/10.3389/fgene.2014.00375

[83] Zhang, Y., Matsushita, N., Eigler, T. and Marban, E. (2013) Targeted MicroRNA Interference Promotes Postnatal Cardiac Cell Cycle Re-Entry. Journal of Regenerative Medicine, 2, 2.

[84] Madonna, R., Engel, F.B., Davidson, S.M., Ferdinandy, P., Gorbe, A., Sluijter, J.P. and Van Laake, L.W. (2015) Stem Cell Aging and Age-Related Cardiovascular Disease: Perspectives of Treatment by Ex-Vivo Stem Cell Rejuvenation. Current Drug Targets, 16, 780-785. https://doi.org/10.2174/1389450116666141205153258

[85] Zhu, Y., Tchkonia, T., Pirtskhalava, T., Gower, A.C., Ding, H., Giorgadze, N., Palmer, A.K., Ikeno, Y., Hubbard, G.B., Lenburg, M., O’Hara, S.P., LaRusso, N.F., Miller, J.D., Roos, C.M., Verzosa, G.C., LeBrasseur, N.K., Wren, J.D., Farr, J.N., Khosla, S., Stout, M.B., McGowan, S.J., Fuhrmann-Stroissnigg, H., Gurkar, A.U., Zhao, J., Colangelo, D., Dorronsoro, A., Ling, Y.Y., Barghouthy, A.S., Navarro, D.C., Sano, T., Robbins, P.D., Niedernhofer, L.J. and Kirkland, J.L. (2015) The Achilles' Heel of Senescent Cells: From Transcriptome to Senolytic Drugs. Aging Cell, 14, 644-658. https://doi.org/10.1111/acel.12344

[86] Zhu, Y., Tchkonia, T., Fuhrmann-Stroissnigg, H., Dai, H.M., Ling, Y.Y., Stout, M.B., Pirtskhalava, T., Giorgadze, N., Johnson, K.O., Giles, C.B., Wren, J.D., Niedernhofer, L.J., Robbins, P.D. and Kirkland, J.L. (2016) Identification of a Novel Senolytic Agent, Navitoclax, Targeting the Bcl-2 Family of Anti-Apoptotic Factors. Aging Cell, 15, 428-435. https://doi.org/10.1111/acel.12445

[87] Villa, F., Carrizzo, A., Spinelli, C.C., Ferrario, A., Malovini, A., Maciag, A., Damato, A., Auricchio, A., Spinetti, G., Sangalli, E., Dang, Z., Madonna, M., Ambrosio, M., Sitia, L., Bigini, P., Cali, G., Schreiber, S., Perls, T., Fucile, S., Mulas, F., Nebel, A., Bellazzi, R., Madeddu, P., Vecchione, C. and Puca, A.A. (2015) Genetic Analysis Reveals a Longevity-Associated Protein Modulating Endothelial Function and Angiogenesis. Circulation Research, 117, 333-345. https://doi.org/10.1161/CIRCRESAHA.117.305875

[88] Villa, F., Malovini, A., Carrizzo, A., Spinelli, C.C., Ferrario, A., Maciag, A., Madonna, M., Bellazzi, R., Milanesi, L., Vecchione, C. and Puca, A.A. (2015) Serum BPIFB4 Levels Classify Health Status in Long-Living Individuals. Immunity \& Ageing, 12, 27. https://doi.org/10.1186/s12979-015-0054-8

[89] Yousef, H., Conboy, M.J., Morgenthaler, A., Schlesinger, C., Bugaj, L., Paliwal, P., Greer, C., Conboy, I.M. and Schaffer, D. (2015) Systemic Attenuation of the TGF-Beta Pathway by a Single Drug Simultaneously Rejuvenates Hippocampal Neurogenesis and Myogenesis in the Same Old Mammal, Oncotarget, 6, 11959-11978. https://doi.org/10.18632/oncotarget.3851 
[90] Avolio, E., Gianfranceschi, G., Cesselli, D., Caragnano, A., Athanasakis, E., Katare, R., Meloni, M., Palma, A., Barchiesi, A., Vascotto, C., Toffoletto, B., Mazzega, E., Finato, N., Aresu, G., Livi, U., Emanueli, C., Scoles, G., Beltrami, C.A., Madeddu, P. and Beltrami, A.P. (2014) EX Vivo Molecular Rejuvenation Improves the Therapeutic Activity of Senescent Human Cardiac Stem Cells in a Mouse Model of Myocardial Infarction. Stem Cells, 32, 2373-2385. https://doi.org/10.1002/stem.1728

[91] Avolio, E., Meloni, M., Spencer, H.L., Riu, F., Katare, R., Mangialardi, G., Oikawa, A., Rodriguez-Arabaolaza, I., Dang, Z., Mitchell, K., Reni, C., Alvino, V.V., Rowlinson, J., Livi, U., Cesselli, D., Angelini, G., Emanueli, C., Beltrami, A.P. and Madeddu, P. (2015) Combined Intramyocardial Delivery of Human Pericytes and Cardiac Stem Cells Additively Improves the Healing of Mouse Infarcted Hearts through Stimulation of Vascular and Muscular Repair. Circulation Research, 116, e81-e94. https://doi.org/10.1161/CIRCRESAHA.115.306146

[92] Vecellio, M., Spallotta, F., Nanni, S., Colussi, C., Cencioni, C., Derlet, A., Bassetti, B., Tilenni, M., Carena, M.C., Farsetti, A., Sbardella, G., Castellano, S., Mai, A., Martelli, F., Pompilio, G., Capogrossi, M.C., Rossini, A., Dimmeler, S., Zeiher, A. and Gaetano, C. (2014) The Histone Acetylase Activator Pentadecylidenemalonate $1 \mathrm{~b}$ Rescues Proliferation and Differentiation in the Human Cardiac Mesenchymal Cells of Type 2 Diabetic Patients. Diabetes, 63, 2132-2147. https://doi.org/10.2337/db13-0731

[93] De Angelis, A., Piegari, E., Cappetta, D., Russo, R., Esposito, G., Ciuffreda, L.P., Ferraiolo, F.A., Frati, C., Fagnoni, F., Berrino, L., Quaini, F., Rossi, F. and Urbanek, K. (2015) SIRT1 Activation Rescues Doxorubicin-Induced Loss of Functional Competence of Human Cardiac Progenitor Cells. International Journal of Cardiology, 189, 30-44. https://doi.org/10.1016/j.ijcard.2015.03.438

[94] Mohsin, S., Khan, M., Nguyen, J., Alkatib, M., Siddiqi, S., Hariharan, N., Wallach, K., Monsanto, M., Gude, N., Dembitsky, W. and Sussman, M.A. (2013) Rejuvenation of Human Cardiac Progenitor Cells with Pim-1 Kinase. Circulation Research, 113, 1169-1179. https://doi.org/10.1161/CIRCRESAHA.113.302302

[95] Hariharan, N., Quijada, P., Mohsin, S., Joyo, A., Samse, K., Monsanto, M., De La Torre, A., Avitabile, D., Ormachea, L., McGregor, M.J., Tsai, E.J. and Sussman, M.A. (2015) Nucleostemin Rejuvenates Cardiac Progenitor Cells and Antagonizes Myocardial Aging. Journal of the American College of Cardiology, 65, 133-147. https://doi.org/10.1016/j.jacc.2014.09.086

[96] Quijada, P., Hariharan, N., Cubillo, J.D., Bala, K.M., Emathinger, J.M., Wang, B.J., Ormachea, L., Bers, D.M., Sussman, M.A. and Poizat, C. (2015) Nuclear Calcium/Calmodulin-Dependent Protein Kinase II Signaling Enhances Cardiac Progenitor Cell Survival and Cardiac Lineage Commitment. The Journal of Biological Chemistry, 290, 25411-25426. https://doi.org/10.1074/jbc.M115.657775

[97] Limke, T.L. and Rao, M.S. (2002) Neural Stem Cells in Aging and Disease. Journal of Cellular and Molecular Medicine, 6, 475-496. https://doi.org/10.1111/j.1582-4934.2002.tb00451.x

[98] Li, X., Yuan, Z., Wei, X., Li, H., Zhao, G., Miao, J., Wu, D., Liu, B., Cao, S., An, D., Ma, W., Zhang, H., Wang, W., Wang, Q. and Gu, H. (2016) Application Potential of Bone Marrow Mesenchymal Stem Cell (BMSCs) Based Tissue-Engineering for Spinal Cord Defect Repair in Rat Fetuses with Spina Bifida Aperta. Journal of Materials Science: Materials in Medicine, 27, 77. https://doi.org/10.1007/s10856-016-5684-7

[99] Dunnett, S.B. (2010) Chapter 55: Neural Transplantation. Handbook of Clinical Neurology, 95, 885-912. https://doi.org/10.1016/S0072-9752(08)02155-6 
[100] Schultz, M.B. and Sinclair, D.A. (2016) When Stem Cells Grow Old: Phenotypes and Mechanisms of Stem Cell Aging. Development, 143, 3-14. https://doi.org/10.1242/dev.130633

[101] Yeh, D.C., Chan, T.M., Harn, H.J., Chiou, T.W., Chen, H.S., Lin, Z.S. and Lin, S.Z. (2015) Adipose Tissue-Derived Stem Cells in Neural Regenerative Medicine. Cell Transplant, 24, 487-492. https://doi.org/10.3727/096368915X686940

[102] Chan, T.M., Chen, J.Y., Ho, L.I., Lin, H.P., Hsueh, K.W., Liu, D.D., Chen, Y.H., Hsieh, A.C., Tsai, N.M., Hueng, D.Y., Tsai, S.T., Chou, P.W., Lin, S.Z. and Harn, H.J. (2014) ADSC Therapy in Neurodegenerative Disorders. Cell Transplant, 23, 549-557. https://doi.org/10.3727/096368914X678445

[103] Cai, W., Zhang, K., Li, P., Zhu, L., Xu, J., Yang, B., Hu, X., Lu, Z. and Chen, J. (2017) Dysfunction of the Neurovascular Unit in Ischemic Stroke and Neurodegenerative Diseases: An Aging Effect. Ageing Research Reviews, 34, 77-87. https://doi.org/10.1016/j.arr.2016.09.006

[104] Farooqui, T. and Farooqui, A.A. (2009) Aging: An Important Factor for the Pathogenesis of Neurodegenerative Diseases. Mechanisms of Ageing and Development, 130, 203-215. https://doi.org/10.1016/j.mad.2008.11.006

[105] Mattson, M.P., Pedersen, W.A., Duan, W., Culmsee, C. and Camandola, S. (1999) Cellular and Molecular Mechanisms Underlying Perturbed Energy Metabolism and Neuronal Degeneration in Alzheimer's and Parkinson's Diseases. Annals of the New York Academy of Sciences, 893, 154-175. https://doi.org/10.1111/j.1749-6632.1999.tb07824.x

[106] Tang, D.G., Tokumoto, Y.M. and Raff, M.C. (1999) Long-Term Culture of Purified Postnatal Oligodendrocyte Precursor Cells. Evidence for an Intrinsic Maturation Program That Plays out over Months. The Journal of Cell Biology, 148, 971-984. https://doi.org/10.1083/jcb.148.5.971

[107] Ruckh, J.M., Zhao, J.W., Shadrach, J.L., van Wijngaarden, P., Rao, T.N., Wagers, A.J. and Franklin, R.J. (2012) Rejuvenation of Regeneration in the Aging Central Nervous System. Cell Stem Cell, 10, 96-103. https://doi.org/10.1016/j.stem.2011.11.019

[108] Kumar, A., Narayanan, K., Chaudhary, R.K., Mishra, S., Kumar, S., Vinoth, K.J., Padmanabhan, P. and Gulyas, B. (2017) Current Perspective of Stem Cell Therapy in Neurodegenerative and Metabolic Diseases. Molecular Neurobiology, 54, 7276-7296. https://doi.org/10.1007/s12035-016-0217-4

[109] Chen, L., Qiu, R. and Xu, Q. (2014) Mesenchymal Stem Cell Therapy for Neurodegenerative Diseases. Journal of Nanoscience and Nanotechnology, 14, 969-975. https://doi.org/10.1166/jnn.2014.9126

[110] Cova, L., Ratti, A., Volta, M., Fogh, I., Cardin, V., Corbo, M. and Silani, V. (2004) Stem Cell Therapy for Neurodegenerative Diseases: The Issue of Transdifferentiation. Stem Cells and Development, 13, 121-131. https://doi.org/10.1089/154732804773099326

[111] Chen, X., Wang, S. and Cao, W. (2018) Mesenchymal Stem Cell-Mediated Immunomodulation in Cell Therapy of Neurodegenerative Diseases. Cellular Immunology, 326, 8-14. https://doi.org/10.1016/j.cellimm.2017.06.006

[112] Marsh, S.E. and Blurton-Jones, M. (2017) Neural Stem Cell Therapy for Neurodegenerative Disorders: The Role of Neurotrophic Support. Neurochemistry International, 106, 94-100. https://doi.org/10.1016/j.neuint.2017.02.006

[113] Ottoboni, L., Merlini, A. and Martino, G. (2017) Neural Stem Cell Plasticity: Advantages in Therapy for the Injured Central Nervous System. Frontiers in Cell and 
Developmental Biology, 5, 52. https://doi.org/10.3389/fcell.2017.00052

[114] Filardo, G., Perdisa, F., Roffi, A., Marcacci, M. and Kon, E. (2016) Stem Cells in Articular Cartilage Regeneration. Journal of Orthopaedic Surgery and Research, 11, 42. https://doi.org/10.1186/s13018-016-0378-x

[115] Lee, W.Y. and Wang, B. (2017) Cartilage Repair by Mesenchymal Stem Cells: Clinical Trial Update and Perspectives. Journal of Orthopaedic Translation, 9, 76-88. https://doi.org/10.1016/j.jot.2017.03.005

[116] Krajewska-Wlodarczyk, M., Owczarczyk-Saczonek, A., Placek, W., Osowski, A. and Wojtkiewicz, J. (2018) Articular Cartilage Aging-Potential Regenerative Capacities of Cell Manipulation and Stem Cell Therapy. International Journal of Molecular Sciences, 19, pii: E623. https://doi.org/10.3390/ijms19020623

[117] Park, C.W., Kim, K.S., Bae, S., Son, H.K., Myung, P.K., Hong, H.J. and Kim, H. (2009) Cytokine Secretion Profiling of Human Mesenchymal Stem Cells by Antibody Array. International Journal of Stem Cells, 2, 59-68. https://doi.org/10.15283/ijsc.2009.2.1.59

[118] Aroen, A. (2011) Stem Cell Therapy for Articular Cartilage Defects. British Medical Bulletin, 99, 227-240. https://doi.org/10.1093/bmb/ldr032

[119] Dinulovic, I., Furrer, R. and Handschin, C. (2017) Plasticity of the Muscle Stem Cell Microenvironment. Advances in Experimental Medicine and Biology, 1041, 141-169. https://doi.org/10.1007/978-3-319-69194-7_8

[120] Larrick, J.W., Larrick, J.W. and Mendelsohn, A.R. (2016) Reversal of Aged Muscle Stem Cell Dysfunction. Rejuvenation Research.

https://doi.org/10.1089/rej.2016.1875

[121] Hwang, A.B. and Brack, A.S. (2018) Muscle Stem Cells and Aging. Current Topics in Developmental Biology, 126, 299-322.

https://doi.org/10.1016/bs.ctdb.2017.08.008

[122] Vahidi Ferdousi, L., Rocheteau, P., Chayot, R., Montagne, B., Chaker, Z., Flamant, P., Tajbakhsh, S. and Ricchetti, M. (2014) More Efficient Repair of DNA Double-Strand Breaks in Skeletal Muscle Stem Cells Compared to Their Committed Progeny. Stem Cell Research, 13, 492-507. https://doi.org/10.1016/j.scr.2014.08.005

[123] Brack, A.S., Conboy, M.J., Roy, S., Lee, M., Kuo, C.J., Keller, C. and Rando, T.A. (2007) Increased Wnt Signaling during Aging Alters Muscle Stem Cell Fate and Increases Fibrosis. Science, 317, 807-810. https://doi.org/10.1126/science.1144090

[124] Sousa-Victor, P., Gutarra, S., Garcia-Prat, L., Rodriguez-Ubreva, J., Ortet, L., Ruiz-Bonilla, V., Jardi, M., Ballestar, E., Gonzalez, S., Serrano, A.L., Perdiguero, E. and Munoz-Canoves, P. (2014) Geriatric Muscle Stem Cells Switch Reversible Quiescence into Senescence. Nature, 506, 316-321.

https://doi.org/10.1038/nature13013

[125] Price, F.D., von Maltzahn, J., Bentzinger, C.F., Dumont, N.A., Yin, H., Chang, N.C., Wilson, D.H., Frenette, J. and Rudnicki, M.A. (2014) Inhibition of JAK-STAT Signaling Stimulates Adult Satellite Cell Function. Nature Medicine, 20, 1174-1181. https://doi.org/10.1038/nm.3655

[126] Tierney, M.T. and Sacco, A. (2016) The Role of Muscle Stem Cell-Niche Interactions during Aging. Nature Medicine, 22, 837-838. https://doi.org/10.1038/nm.4159

[127] Cosgrove, B.D., Gilbert, P.M., Porpiglia, E., Mourkioti, F., Lee, S.P., Corbel, S.Y., Llewellyn, M.E., Delp, S.L. and Blau, H.M. (2014) Rejuvenation of the Muscle Stem Cell Population Restores Strength to Injured Aged Muscles. Nature Medicine, 20, 255-264. https://doi.org/10.1038/nm.3464 
[128] Zhang, H., Ryu, D., Wu, Y., Gariani, K., Wang, X., Luan, P., D’Amico, D., Ropelle, E.R., Lutolf, M.P., Aebersold, R., Schoonjans, K., Menzies, K.J. and Auwerx, J. (2016) $\mathrm{NAD}(+)$ Repletion Improves Mitochondrial and Stem Cell Function and Enhances Life Span in Mice. Science, 352, 1436-1443. https://doi.org/10.1126/science.aaf2693

[129] Elabd, C., Cousin, W., Upadhyayula, P., Chen, R.Y., Chooljian, M.S., Li, J., Kung, S., Jiang, K.P. and Conboy, I.M. (2014) Oxytocin Is an Age-Specific Circulating Hormone That Is Necessary for Muscle Maintenance and Regeneration. Nature Communications, 5, 4082. https://doi.org/10.1038/ncomms5082

[130] Brack, A.S. and Munoz-Canoves, P. (2016) The Ins and Outs of Muscle Stem Cell Aging. Skeletal Muscle, 6, 1. https://doi.org/10.1186/s13395-016-0072-z

[131] Shadrach, J.L. and Wagers, A.J. (2011) Stem Cells for Skeletal Muscle Repair. Philosophical Transactions of the Royal Society B: Biological Sciences, 366, 2297-2306. https://doi.org/10.1098/rstb.2011.0027

[132] Wagers, A.J. and Conboy, I.M. (2005) Cellular and Molecular Signatures of Muscle Regeneration: Current Concepts and Controversies in Adult Myogenesis. Cell, 122, 659-667. https://doi.org/10.1016/j.cell.2005.08.021

[133] Peault, B., Rudnicki, M., Torrente, Y., Cossu, G., Tremblay, J.P., Partridge, T., Gussoni, E., Kunkel, L.M. and Huard, J. (2007) Stem and Progenitor Cells in Skeletal Muscle Development, Maintenance, and Therapy. Molecular Therapy, 15, 867-877. https://doi.org/10.1038/mt.sj.6300145

[134] Fan, C.M., Li, L., Rozo, M.E. and Lepper, C. (2012) Making Skeletal Muscle from Progenitor and Stem Cells: Development versus Regeneration. Wiley Interdisciplinary Reviews. Developmental Biology, 1, 315-327. https://doi.org/10.1002/wdev.30 